\title{
EDITORIAL
}

\section{Pandemi Covid 19, Stabilitas Keamanan, Daya Beli Masyarakat dan Pertumbuhan ERonomi Nasional}

Konsep keamanan mengalami pergeseran isu-isu keamanan tradisional menuju pada isu keamanan non-tradisional terutama pada people oriented yang berkembang menjadi multidimensional seperti ekonomi, sosial dan lingkungan yang berkaitan dan tidak terpisahkan satu sama lain (Buzan, 1991:433). Barry Buzan menyatakan terdapat lima dimensi yang saling terkait, yakni : military, political, economic, societal dan environmental.

Stabilitas Makro ekonomi, pertumbuhan industri strategis, dan stabilitas keamanan berpengaruh secara simultan terhadap pertumbuhan ekonomi. Temuan ini menunjukkan bahwa integrasi pembangunan stabilitas keamanan bersama-sama dengan peningkatan pertumbuhan industri strategis dan stabilitas makroekonomi secara sinergis memiliki kemampuan untuk meningkatkan pertumbuhan ekonomi.

Maraknya pandemi Covid-19 membuat lesunya IHSG dan saham-saham yang ada di Bursa Efek Indonesia. Pandemi Covid-19 juga menyebabkan banyaknya Pemutusan Hubungan Kerja (PHK) oleh perusahaan, rumah makan, restoran, kafe, dan lain sebagainya yang terkena imbas Covid-19.

Perekonomian Indonesia semakin melemah demikian juga nilai tukar Rupiah di pasar saham Nasdaq. Hal tersebut disebabkan karena masyakat Indonesia yang menerapkan sistem lockdown dan PSBB, sehingga perekonomian masyarakat tidak bergairah.

Hasil ini menunjukkan bahwa sinyal beli dan sinyal jual yang dihasilkan oleh indikator MACD adalah akurat dan dapat digunakan dalam perdagangan saham.

Bagi para investor disarankan lebih berhati-hati dalam melakukan perdagangan saat kondisi pasar sedang bearish karena pergerakan saham sangat fluktuatif dan lebih spekulatif dibanding perdagangan saham pada saat kondisi pasar bullish.

Tim Editorial 